tinental universities or institutions for research in chemistry, physics or some other allied scientific subject. They will be awarded to graduates of universities in the United Kingdom or the Republic of Ireland. The basic award for Fellows who wish to continue postdoctorate studies will be $£ 800$ per annum plus allowances. For candidates who have obtained a first degree in science and wish to undergo training in research, the basic award will be $£ 500$ per annum plus allowances. The total value of each fellowship will be determined by the advisory panel, and will be sufficient to cover the Fellow's living and other expenses (including fees and cost of travel) during the tenure of his fellowship, which will be for one year, renewable for a further one or three years. Applications should be made in duplicate on forms obtainable from the Secretary of the Ciba Fellowship Trust, Ciba (A.R.L.), Ltd., Duxford, Cambridge. The closing date for such applications is January $31,1959$.

\section{C.S.I.R.O. Wool Research Laboratories}

ThE three Wool Textile Research Laboratories of the Commonwealth Scientific and Industrial Research Organization (Australia) have been made divisions of the Organization. The Melbourne Laboratory becomes the Division of Protein Chemistry, the Sydney Laboratory the Division of Textile Physics, and the Geelong Laboratory the Division of Textile Industry. In future this group of divisions will be called the C.S.I.R.O. Wool Research Laboratories. These laboratories were established in 1949. The officer-in-charge of the Melbourne Laboratory, Dr. F. G. Lennox, becomes the chief of the Division of Protein Chemistry; the officer-in-charge of the Sydney Laboratory, Mr. V. D. Burgmann, becomes chief of the Division of Textile Physics; and the officer-in-charge of the Geelong Laboratory, Dr. M. Lipson, becomes chief of the Division of Textile Industry.

\section{Annual Conference of Educational Associations}

The forty-second annual conference of Educational Associations will be held in the College of Preceptors, 2 and 3 Bloomsbury Square, London, W.C.1, during December 30-January 2. Dr. B. E. Lawrence, chief education officer, Essex, will deliver the presidential address entitled "Partnership in Education" on the eve of the Conference in the assembly hall of the Institute of Education, University of London. During the Conference, and under the auspices of the School Nature Study Union and the Universities Federation for Animal Welfare, Miss F. R. Elwell, science producer, B.B.C. Television for Schools, will give a lecture on "Animals and Television" in the College of Preceptors on December 31 at 2.30 p.m. All meetings at the Conference are open free of charge and without tickets. Further information can be obtained from the Conference Secretary, 2 and 3 Bloomsbury Square, London, W.C.1.

\section{Geographical Association Summer Schools}

THE Geographical Association is organizing two summer schools in 1959. The first, to be held in Spain during August 12-27, under the direction of Dr. M. J. Houston (Oxford), will deal with Mediterranean geography. On this course members will study the land-forms and vegetation climaxes on the northern and southern flanks of the central Pyrenees; contrasts in relief, vegetation and land use in the central cordillera of Spain (field excursions from
Madrid); and distinctive types of land use and settloment in Valencia and Catalonia (field excursions from Valencia and Barcelona). Urban studies will be made in Madrid, Valencia and Barcelona. The second, to be in Switzerland during August 18September 2, will consist of Alpine studies centred on Orsières in the Pennine Alps, near the Italian and French frontiers. It will be under the direction of Mr. R. C. Honeybone (London). Members will study the Alpine environment of the Drance River and its tributaries, and its physical and cultural relations with, to the north, the Rhône valley (Martigny and Sion) and, to the south, Val d'Aosta via Grand St. Bernard; a field excursion to study glacial features near Chamonix will be included in the programme. Members' field work and several of the field excursions will be done on foot, which will involve hill-walking and climbing but not rock-climbing. Further details and forms of application can be obtained from the Assistant Secretary, Geographical Association, c/o The Park Branch Library, Duke Street, Sheffield, 2.

University News:

London

Dr. J. A. LAING, reader in the University of Bristol, has been appointed to the Courtauld chair of animal husbandry and veterinary hygiene tenable at the Royal Veterinary College.

The title of professor emeritus of plant physiology in the University has been conferred on Prof. F. G. Gregory on his resignation on December 31 from the chair of plant physiology at the Imperial College of Science and Technology, which he has held since 1937.

\section{Announcements}

ThE insignia of C.B.E. has been presented by the British Ambassador in Rome to Prof. Domenico Marotta. As director-general of the Istituto Superiore di Sanità in Rome, Prof. Marotta has an important position in chemical science and industry in Italy, and organized the meeting this year of the Eighth National Congress of the Italian Chemical Society jointly with the Society of Chemistry and Industry.

THe Worshipful Company of Founders has awarded its medal in bronze to the following Liverymen of the Company to mark "their services to the Art and Mystery of Founding and to the Company": Dr. J. G. Pearce, director of the British Cast Iron Research Association; Dr. J. E. Hurst, managing director of Bradley and Foster, Ltd., Darlaston; Mr. C. C. Booth, director of Booth and Brooks, Ltd., Burnham-on-Crouch; and Mr. J. J. Sheehan, lately managing director of the Coneygrw Foundry, Ltd.

Mr. William Barr has been nominated by the Council for election as president of the Iron and Steel Institute for the 1959-1960 session. $\mathrm{He}$ will take office at the general meeting on May 6.

IN February 1956 the National Metallurgical Research Laboratory of the Council of Scientific and Industrial Research, Jamshedpur, India, held a symposium on "Production, Properties and Application of Alloy and Special Steels". The forty-five papers contributed are now published (pp. vi +488 . Jamshedpur: National Metallurgical Laboratory, 1958), and cover all the main aspects of the subject. Most of them are from Indian workers, but a dozen or so represent contributions from metallurgists in Europe and America. 